\title{
Perencanaan Angkutan Wisata di Pulau Beras Basah Kota Bontang
}

\author{
${ }^{1}$ Louise Elizabeth Radjawane, ${ }^{2}$ Anas Ibnu Setiawan, ${ }^{3}$ Eka Arista, ${ }^{4}$ Aji ronaldo \\ ${ }^{1}$ Universitas Kristen Indonesia Paulus \\ ${ }^{2}$ Universitas Kristen Indonesia Paulus \\ ${ }^{3}$ Direktorat Jenderal Kereta Api \\ ${ }^{4}$ Politeknik Transportasi Darat Indonesia-STTD \\ Email: eliz_louise@yahoo.com
}

\begin{abstract}
Abstrak
Kota Bontang disamping menyimpan kekayaan sumber daya alamnya juga memiliki potensi wisata yang tidak kalah dengan daerah lainnya. Salah satu potensi wisata di kota Bontang adalah Pantai Beras Basah yang terletak di Pulau Beras Basah yang banyak dikunjungi oleh wisatawan lokal maupun dari luar daerah. Akan tetapi tempat wisata ini belum memiliki angkutan yang memadai. Oleh karena itu penelitian ini bertujuan untuk membuat perencanaan angkutan wisata di pulau Beras Basah Kota Bontang. Penelitian ini, desain yang digunakan adalah desain kausal komparatif, karena menerangkan hubungan sebab akibat. Hasil penelitian menunjukkan Peningkatan pertumbuhan wisatawan setiap tahunnya setiap tahunnya meningkat sebesar 0,12 atau $12 \%$. Ini menunjukkan bahwa kawasan wisata bahari Pulau Beras Basah banyak dikunjungi wisatawan, baik wisatawan dari dalam Kota Bontang ataupun luar Kota Bontang. Untuk angkutan wisata bahari Pulau Beras Basah akan mengalami titik impas pada load faktor BEP 75\% dari load faktor kapal rencana $70 \%$.
\end{abstract}

Kata Kunci: Transportasi, Moda Angkutan, Angkutan Wisata, Perencanaan.

\begin{abstract}
Bontang City besides saving its natural resource wealth also has tourism potential that is not inferior to other regions. One of the tourism potentials in the city of Bontang is Beras Basah Beach which is located on Beras Basah Island which is visited by many local and foreign tourists. However, this tourist spot does not have adequate transportation. Therefore, this study aims to make a tourism transportation plan on Beras Basah Island, Bontang City. In this study, the design used is a comparative causal design, because it explains the causal relationship. The results of the study showed that the increase in tourist growth each year each year increased by 0.12 or $12 \%$. This shows that the marine tourism area of Beras Basah Island is visited by many tourists, both tourists from within Bontang City or outside Bontang City. For marine tourism transportation, Beras Basah Island will break even at a BEP load factor of $75 \%$ of the planned ship load factor of $70 \%$.
\end{abstract}

Keywords: Transportation, Mode of Transport, Tourist Transportation, Planning

\section{A. PENDAHULUAN}

Pariwisata merupakan berbagai macam kegiatan wisata yang didukung oleh berbagai fasilitas serta layanan yang disediakan masyarakat, pengusaha, Pemerintah dan Pemerintah Daerah. Menurut Salah Wahab dalam Oka A Yoeti, 1994:116), pariwisata merupakan suatu aktivitas manusia yang dilakukan secara sadar yang mendapatkan pelayanan secara bergantian diantara orang-orang dalam suatu negara itu sendiri atau luar negeri (meliputi pendiaman orangorang dari daerah lain) untuk mencari kepuasan yang beraneka ragam dan berbeda dengan apa yang dialaminya dimana seseorang memperoleh pekerjaan tetap. Jadi pariwisata itu merupakan aktivitas manusia yang dilakukan secara sadar dalam mendapatkan pelayanan berbeda dari biasanya baik diluar negeri maupun didalam negeri guna mencari kepuasan dengan didukung 
berbagai fasilitas serta layanan yang disediakan masyarakat, pengusaha, Pemerintah dan Pemerintah Daerah.

Kalimantan merupakan salah satu pulau di Indonesia yang memiliki berbagai jenis suku, ras dan budaya yang beragam. Disamping itu Pulau Kalimantan merupakan pulau terluas di Indonesia. Salah satu provinsi yang ada di Kalimantan adalah Provinsi Kalimantan Timur. Kalimantan Timur wilayahnya terbagi menjadi 10 bagian yakni Kabupaten Berau, Kabupaten Kutai Barat, Kabupaten Kutai Kartanegara, kabupaten Kutai Timur, Kabupaten Mahakam Ulu, Kabupaten Paser, Kabupaten Penajam Paser Utara, Kota Balikpapan, Kota Samarinda, dan Kota Bontang. Perkembangan pariwisata di Kalimantan Timur kian berkembang cukup pesat, hal ini terlihat dari kunjungan wisatawan yang makin meningkat tiap tahunnya. Kalimantan Timur yang merupakan bagian dari Kepulauan Maritim dan pulau terbesar di Indonesia yang memiliki potensi wisata yang dapat dikembangkan dan kemudian menimbulkan daya tarik. Daya tarik wisata di Kalimantan Timur cukup beragam, baik daya tarik wisata alam, budaya, dan minat khusus, diantaranya objek wisata Pulau Derawan, Kebun Raya Samarinda, Taman Nasional Kutai, Kawasan Bukit Bangkirai, Pulau Beras Basah dan lain - lain.

Kota Bontang adalah bagian dari Provinsi Kalimantan Timur. Kota Bontang terletak di bagian timur yang berdekatan dengan Selat Makassar sehingga wilayahnya sebagian besar di dominasi oleh perairan. Disamping keunggulan dalam sektor industri, di sektor pariwisata pun Kota Bontang memiliki kawasan yang dapat di kembangkan sebagai daya tarik wisata. Salah satu kawasan wisata yang ada di Bontang adalah Pantai Beras Basah, pantai ini terdapat di sebuah pulau yang bernama sama dengan pantainya, yaitu Pulau Beras Basah. Pulau ini sebagai salah satu tujuan wisata yang cukup dikenal di Bontang, Kalimantan Timur. Pulau ini terbilang kecil, namun demikian pulau ini memiliki daya tarik tersendiri yaitu pantai dengan pasir putihnya, air yang jernih dan berwarna biru kehijauan, banyaknya pohon - pohon yang rimbun yang menambah sejuk udara di tempat ini, terdapat pula menara putih yang berbentuk kerucut yang menyerupai menara mercusuar, jembatan kayu yang menjorok ke laut, terdapat juga pondokan sederhana, arena permainan, sebuah rumah untuk penjaga pulau, serta pemandangan alam bawah laut yang menawan, sehingga di pulau ini para wisatawan bisa bermain pasir, berenang bahkan diving dan snorkling.

Berdasarkan data wisatawan ke Pulau Beras Basah lima tahun terakhir menunjukkan peningkatan jumlah kunjungan wisatawan. Peningkatan jumlah kunjungan wisatawan dapat terlihat pada Tabel 1 .

Tabel 1 Data Kunjungan Wisatawan

\begin{tabular}{|c|c|r|}
\hline No & Tahun & Jumlah Wisatawan (orang) \\
\hline 1. & 2009 & 28.222 \\
\hline 2. & 2010 & 29.522 \\
\hline 3. & 2011 & 30.824 \\
\hline 4. & 2012 & 32.804 \\
\hline 5. & 2013 & 37.236 \\
\hline 6. & 2014 & 41.698 \\
\hline
\end{tabular}

Sumber : Dinas Kebudayaan dan Pariwisata Kota Bontang, 2014

Pulau ini banyak dikunjungi masyarakat Kota Bontang pada khususnya dan masyarakat luar Kota Bontang pada umumnya seperti Jakarta, Bandung, Surabaya, Balikpapan, Samarinda, 
Kutai Timur, dan Kutai Kartanegara. Tempat wisata ini ramai dikunjungi wisatawan pada hari Sabtu, Minggu dan hari libur nasional. Para wisatawan berkunjung ke Pulau Beras Basah dengan maksud untuk berwisata, ada yang langsung menuju pelabuhan ada pula wisatawan yang berasal dari luar Kota Bontang menginap di hotel yang ada di Kota Bontang. Perjalanan wisatawan menuju Pulau Beras Basah belum diatur dengan sistem penjadwalan yang tetap dan teratur. Untuk menuju Pulau Beras Basah wisatawan harus menggunakan kapal nelayan dengan sistem sewa dan kesepakatan dengan pemilik kapal, dengan harga sewa kapal Rp 500.000,00 hingga Rp 1.000.000,00 untuk satu kali perjalanan. Terdapat tiga jenis kapal yang disewakan dengan kapasitas penumpang 15 orang, 25 orang, hingga 40 orang.

Pelabuhan Tanjung Laut adalah lintas awal yang digunakan wisatawan untuk menuju Pulau

Beras Basah. Waktu perjalanan yang ditempuh adalah sebesar 60 menit dari pelabuhan untuk sampai ke Pulau Beras Basah. Jarak dari Pelabuhan Tanjung Laut menuju Pulau Beras Basah adalah 6,22 mil (10 km). Kondisi eksisting saat ini adalah, para wisatawan menggunakan kapal penangkap ikan nelayan untuk melakukan perjalanan. Mengingat belum adanya kapal penumpang (bukan kapal nelayan) yang memadai untuk melayani perjalanan angkutan penumpang menuju Pulau Beras Basah, maka dianggap perlu untuk melakukan kajian mengenai perencanaan angkutan khusus penumpang guna melayani perjalanan pariwisata ke Pulau Beras Basah.

Hal ini didukung juga dengan adanya Rencana Tata Ruang Wilayah (RTRW) Kota Bontang yakni bahwa Pulau Beras Basah akan dikembangkan sebagai salah satu wisata bahari. Potensi ini perlu mendapat perhatian khusus dalam menentukan seberapa besar kebutuhan sebagai pengembangan, penetapan pola perencanaan biaya operasional kapal serta sistem penjadwalan dan rencana operasional angkutan wisata bahari yang terpadu untuk melayani pergerakan penumpang menuju Pulau Beras Basah. Dengan demikian, hasil yang diharapkan menjadi input bagi Pemerintah Daerah dalam merumuskan kebijakan pengembangan sistem transportasi angkutan untuk mendukung Pulau Beras Basah sebagai wisata bahari yang dimiliki Kota Bontang.

Selain itu, transportasi berperan sebagai penunjang, pendorong dan penggerak bagi pertumbuhan daerah yang berpotensi dalam pengembangan pariwisata. Sistem transportasi baik udara, laut maupun kereta api apapun moda yang digunakan masyarakat ujungnya akan melewati jalan darat. Adanya angkutan wisata bahari yang terpadu dengan moda darat dan fasilitasnya perlu diterapkan pada angkutan wisata menuju Pulau Beras Basah. Keterpaduan moda antara angkutan air untuk pariwisata yang terpadu dengan moda angkutan di darat, akan mempermudah wisatawan menuju Pulau Beras Basah. Belum adanya sistem angkutan wisata yang terpadu dengan fasilitas darat untuk melayani dari atau menuju Pulau Beras Basah baik melayani wisatawan yang berasal dari Kota Bontang dan wisatawan dari luar Kota Bontang. Maka perlu adanya penyediaan moda dan fasilitas pendukung, sehingga wisatawan yang akan melakukan wisata ke Pulau Beras Basah menjadi mudah dan terintegrasi dengan baik.

\section{B. METODE}

Dalam penelitian ini, desain yang digunakan adalah desain kausal komparatif, karena menerangkan hubungan sebab akibat. Pada penelitian ini hubungan yang dimaksud adalah adanya jenis tata guna lahan (pariwisata) yang mempunyai pengaruh terhadap aktivitas pergerakan (intensitas) pada tata guna lahan tersebut. Dengan timbulnya pergerakan maka adanya kebutuhan sarana penumpang serta pengaturan pola operasional untuk menunjang sarana yang tersedia. Adapun pokok permasalahan tersebut dapat dilihat pada gambar rancangan penelitian berikut : 


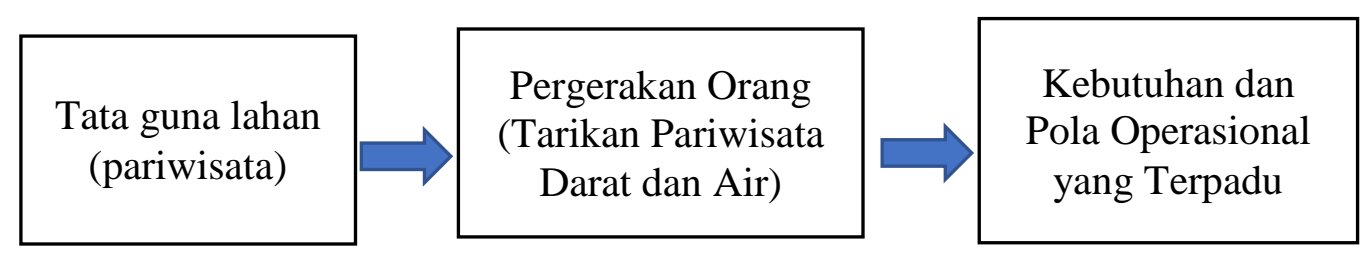

Gambar 1 Rancangan Penelitian

\section{HASIL DAN PEMBAHASAN}

\section{Analisis Karakteristik Wisatawan}

Dari analisis karakteristik wisatawan Pulau Beras Basah, wisatawan yang mengunjungi Pulau Beras Basah baik pada hari kerja dan hari libur tertinggi adalah karyawan swasta, untuk rata - rata usia wisatawan yang banyak berwisata ke Pulau Beras Basah tersebut adalah usia 21 - 30 tahun. Selain itu wisatawan yang berkunjung ke Pulau Beras Basah adalah wisatawan yang berasal dari dalam Kota Bontang ataupun wisatawan dari luar Kota Bontang, sehingga waktu perjalanan wisatawan menuju Pulau Beras Basah untuk wisatawan dari dalam Kota Bontang adalah $\leq 30$ menit, wisatawan yang berasal dari luar Kota Bontang adalah $\geq 61$ menit, moda yang digunakan para wisatawan untuk menuju ke Pulau Beras Basah dari Pelabuhan Tanjung Laut adalah dengan menggunakan kapal ikan nelayan dengan sistem tarif kesepakatan dengan pemilik kapal. Maka para wisatawan menginginkan adanya moda yang sesuai untuk melayani seperti adanya kapal wisata sehingga dapat terjamin keselamatan dan moda yang melayani bisa memberikan rasa nyaman bagi wisatawan untuk menikmati liburan ataupun wisata bahari ke Pulau Beras Basah tersebut.

Wisatawan yang menuju Pulau Beras Basah berasal dari masing - masing zona asal. Ada yang berasal dari zona di dalam Kota Bontang dan ada pula yang berasal dari zona luar Kota Bontang. Zona yang berasal dari dalam Kota Bontang yaitu Bontang Baru, Gunung Elai, Bontang Kuala, Api - api, Tanjung Laut, Tanjung Laut Indah, Berbas Pantai, Berbas Tengah, Satimpo, Loktuan, Guntung, Belimbing, Telihan, Kanaan, serta Bontang Lestari. Sedangkan untuk Kutai Timur, Kutai Kartanegara, Samarinda, Balikpapan, Tenggarong, Penajam, Jakarta dan lainnya merupakan zona luar Kota Bontang. Berikut merupakan jumlah pergerakan wisatawan dari zona asal menuju Pelabuhan Tanjung Laut (Pulau Beras Basah).

\section{Analisis Rencana Operasional Angkutan Wisata}

a. Analisis Forcasting Penumpang Angkutan Wisata Pulau Beras Basah

Dalam melakukan analisis terhadap wisatawan lima tahun terakhir ini dilakukan dengan beberapa jenis trendline, adapun tingkat penyimpangan atau nilai R2 yang digunakan untuk proyeksi wisatawan adalah jenis trendline Polynomial dengan tingkat penyimpangan atau nilai $\mathrm{R}^{2}$ 0,9953. Berdasarkan hasil penelitian diperoleh persamaan model yang akan digunakan untuk melakukan proyeksi terhadap wisatawan Pulau Beras Basah tahun 2015 - 2032, maka hasil proyeksi wisatawan dengan bentuk fungsi :

$$
y=505,89 x 2-898,34 x+28856
$$

Hasil nya dilihat pada Tabel 1 sebagai berikut : 
Tabel 1 Hasil Proyeksi Persamaan Model (Trendline Polynomial) Wisatawan Pulau Beras Basah

\begin{tabular}{|c|c|r|}
\hline No & Tahun & $\begin{array}{c}\text { Jumlah Wisatawan } \\
\text { (Orang) }\end{array}$ \\
\hline 1. & 2015 & 47.356 \\
\hline 2. & 2016 & 54.046 \\
\hline 3. & 2017 & 61.748 \\
\hline 4. & 2018 & 70.462 \\
\hline 5. & 2019 & 80.187 \\
\hline 6. & 2020 & 90.924 \\
\hline 7. & 2021 & 102.673 \\
\hline 8. & 2022 & 115.434 \\
\hline 9. & 2023 & 129.206 \\
\hline 10. & 2024 & 143.990 \\
\hline 11. & 2025 & 159.786 \\
\hline 12. & 2026 & 176.594 \\
\hline 13. & 2027 & 194.414 \\
\hline 14. & 2028 & 213.245 \\
\hline 15. & 2029 & 233.088 \\
\hline 16. & 2030 & 253.943 \\
\hline 17. & 2031 & 275.810 \\
\hline 18. & 2032 & 298.688 \\
\hline
\end{tabular}

\section{b. Analisis Kapal Kondisi Eksisting}

Selanjutnya yaitu adalah analisis pola operasi kapal pada kondisi eksisting. Pola operasi ini dibuat untuk mengetahui pola operasi kapal yang sudah berjalan saat ini di lapangan. Dimana pada daerah studi yaitu angkutan yang digunakan wisatawan saat ini adalah masih menggunakan kapal ikan nelayan. Sehingga belum tersedia sistem tarif dan jadwal yang tetap dan teratur. Dalam sistem tarif masih menggunakan tarif berdasarkan sistem kesepakatan dengan pemilik kapal. Pola operasi angkutan wisata bahari pada kondisi eksisting dilakukan untuk tahun 2015. Dimana jumlah wisatawan tersebut di dapatkan dari hasil forcasting wisatawan, data jumlah wisatawan lima tahun terakhir. Setelah dilakukan analisis forcasting wisatawan maka didapatkan jumlah wisatawan pada tahun 2015 sebanyak 47.352 wisatawan. Pola operasi tahun 2015 digunakan untuk mengetahui sistem operasi yang ada saat ini dalam menentukan frekuensi kapal, jumlah kapal, serta mengatur headway keberangkatan kapal untuk melayani wisatawan. Selain itu pola operasi ini juga berfungsi sebagai komponen pembentuk biaya operasional kapal dalam penentuan tarif yang berlaku untuk melayani wisatawan, sehingga tarif yang berlaku dapat ditetapkan sesuai dengan perhitungan pola operasi dan biaya operasional kapal yang ada.

Setelah dilakukan perhitungan terhadap pola operasi kapal pada kondisi eksisting selanjutnya dilakukan perhitungan tarif. Tarif wisatawan pada angkutan wisata bahari lintas Pelabuhan Tanjung Laut - Pulau Beras Basah yang berlaku pada saat ini adalah tarif berdasarkan hasil kesepakatan bersama pemilik kapal. Untuk mengetahui kelayakan tarif yang berlaku sekarang, perlu dilakukan evaluasi perhitungan tarif berdasarkan dari Biaya Operasional Kapal yang dihitung berdasarkan Peraturan Menteri Nomor 18 Tahun 2012 Tentang Perubahan Atas 
Keputusan Menteri Perhubungan Nomor 58 Tahun 2003 Tentang Mekanisme Penetapan dan Formulasi Perhitungan Tarif Angkutan Penyeberangan. Dari perhitungan tersebut dapat dihitung tarif yang seharusnya dikenakan untuk tiap wisatawan, kemudian diadakan perbandingan antara tarif yang berlaku saat ini, selain itu dilakukan juga perhitungan pendapatan operator kapal serta keuntungan pihak operator.

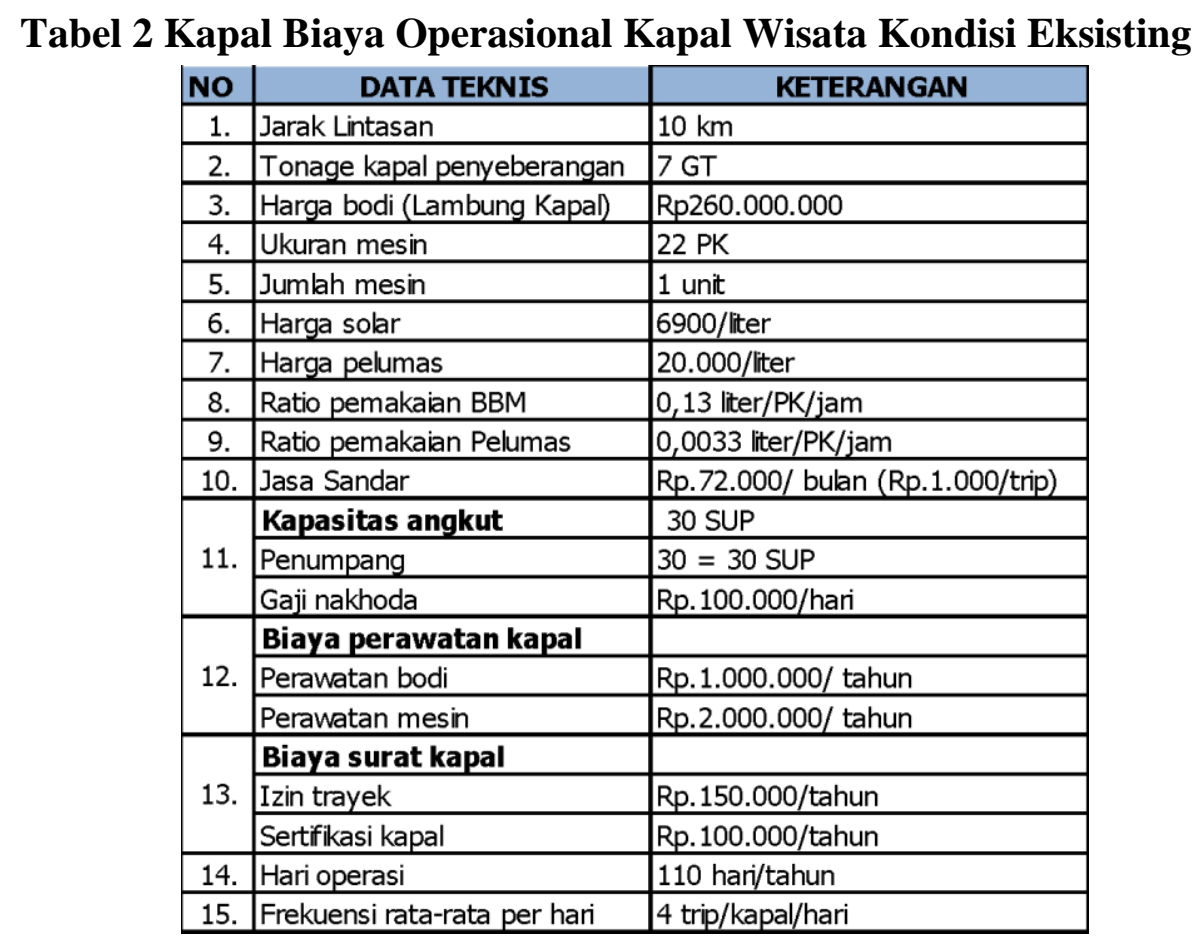

\section{c. Analisis Kapal Kondisi Rencana}

Selanjutnya yaitu adalah analisis pola operasi kapal pada kondisi rencana. Pola operasi ini dibuat untuk mengetahui pola operasi kapal pada kondisi rencana. Dimana pada daerah studi yaitu angkutan yang digunakan wisatawan saat ini adalah masih menggunakan kapal ikan nelayan. Sehingga belum tersedia sistem tarif dan jadwal yang tetap dan teratur. Dalam sistem tarif masih menggunakan tarif berdasarkan sistem kesepakatan dengan pemilik kapal. Pola operasi angkutan wisata bahari pada kondisi rencana dilakukan untuk tahun 2018. Dimana berdasarkan hasil wawancara terhadap Dinas Kebudayaan dan Pariwisata Kota Bontang mengenai anggaran pemerintah daerah Kota Bontang untuk perencanaan angkutan wisata bahari tersebut dilakukan untuk tahun 2018. Adapun jumlah wisatawan pada tahun 2018 dari hasil analisis forcasting wisatawan, didapatkan jumlah wisatawan pada tahun 2018 sebanyak 70.462 wisatawan. Pola operasi tahun 2018 digunakan untuk mengetahui sistem operasi yang akan direncanakan dalam menentukan frekuensi kapal, jumlah kapal, serta mengatur headway keberangkatan kapal untuk melayani wisatawan. Selain itu pola operasi ini juga berfungsi sebagai komponen pembentuk biaya operasional kapal dalam penentuan tarif yang berlaku untuk melayani wisatawan pada kondisi rencana, sehingga tarif yang berlaku dapat ditetapkan sesuai dengan perhitungan pola operasi dan biaya operasional kapal yang ada.

Setelah dilakukan perhitungan terhadap pola operasi kapal pada kondisi rencana tahun 2018 selanjutnya dilakukan perhitungan tarif. Tarif wisatawan pada angkutan wisata bahari lintas Pelabuhan Tanjung Laut - Pulau Beras Basah yang berlaku pada saat ini adalah tarif berdasarkan 
hasil kesepakatan bersama pemilik kapal. Untuk mengetahui kelayakan tarif yang berlaku pada kondisi rencana, perlu dilakukan evaluasi perhitungan tarif berdasarkan dari Biaya Operasional Kapal yang dihitung berdasarkan Peraturan Menteri Nomor 18 tahun 2012 tentang perubahan atas Keputusan Menteri Perhubungan Nomor 58 Tahun 2003 tentang Mekanisme Penetapan dan Formulasi Perhitungan Tarif Angkutan Penyeberangan. Dari perhitungan tersebut dapat dihitung tarif yang seharusnya dikenakan untuk tiap wisatawan, kemudian diadakan perbandingan antara tarif yang berlaku saat ini, selain itu dilakukan juga perhitungan pendapatan operator kapal serta keuntungan pihak operator. Berikut merupakan perhitungan tarif biaya operasional kapal pada kondisi rencana dengan asumsi komponen BOK dua kapal.

\section{Tabel 2 Kapal Biaya Operasional Kapal Wisata Kondisi Eksisting}

\begin{tabular}{|c|c|c|}
\hline No & DATA TEKNIS & KETERANGAN \\
\hline 1. & Jarak Lintasan & $10 \mathrm{~km}$ \\
\hline 2. & Tonage kapal penyeberangan & $6 \mathrm{GT}$ \\
\hline 3. & Harga Kapal & $\operatorname{Rp} 1.000 .000 .000,-$ \\
\hline 4. & Ukuran mesin & 175 PK \\
\hline 5. & Jumlah mesin & 6 unit \\
\hline 6. & Harga solar & $7400 /$ iter \\
\hline 7. & Harga pelumas & $25.000 /$ iter \\
\hline 8. & Ratio pemakaian BBM & 0,13 liter/PK/jam \\
\hline 9. & Ratio pemakaian Pelumas & 0,0033 Itter/PK/jam \\
\hline 10. & Jasa Sandar & Rp. $840.000 /$ bulan (Rp. $1.000 /$ trip) \\
\hline \multirow{4}{*}{11.} & Kapasitas angkut & 80 SUP \\
\hline & Penumpang & $80=80$ SUP \\
\hline & Gaji Nahkoda & Rp.150.000/hari \\
\hline & Anak Buah Kapal & Rp. $100.000 /$ hari \\
\hline \multirow{3}{*}{12.} & Biaya perawatan kapal & \\
\hline & Perawatan Lambung Kapal & Rp.4.000.000/tahun \\
\hline & Perawatan Mesin & Rp.6.000.000/tahun \\
\hline \multirow{3}{*}{13.} & Biaya surat kapal & \\
\hline & Izin trayek & Rp. $400.000 /$ tahun \\
\hline & Sertifikasi kapal & Rp. $300.000 /$ tahun \\
\hline 14. & Hari operasi & 330 hari/tahun \\
\hline 15. & Frekuensi rata-rata per hari & 6 trip/hari \\
\hline
\end{tabular}

\section{d. Load Factor Break Even Point}

Dalam menghitung load faktor break even point, terdapat biaya yang digunakan untuk men=nghitung biaya operasional kendaraan yang terdiri dari biaya tetap dan biaya tidak tetap. Berdasarkan dari analisis diperoleh load faktor BEP 75\% dari load faktor kapal rencana 70\%, maka titik impas atau dinyatakan sudah menguntungkan saat load faktor BEP 75\%. Adapun grafik break event dapat dilihat pada Gambar 2.

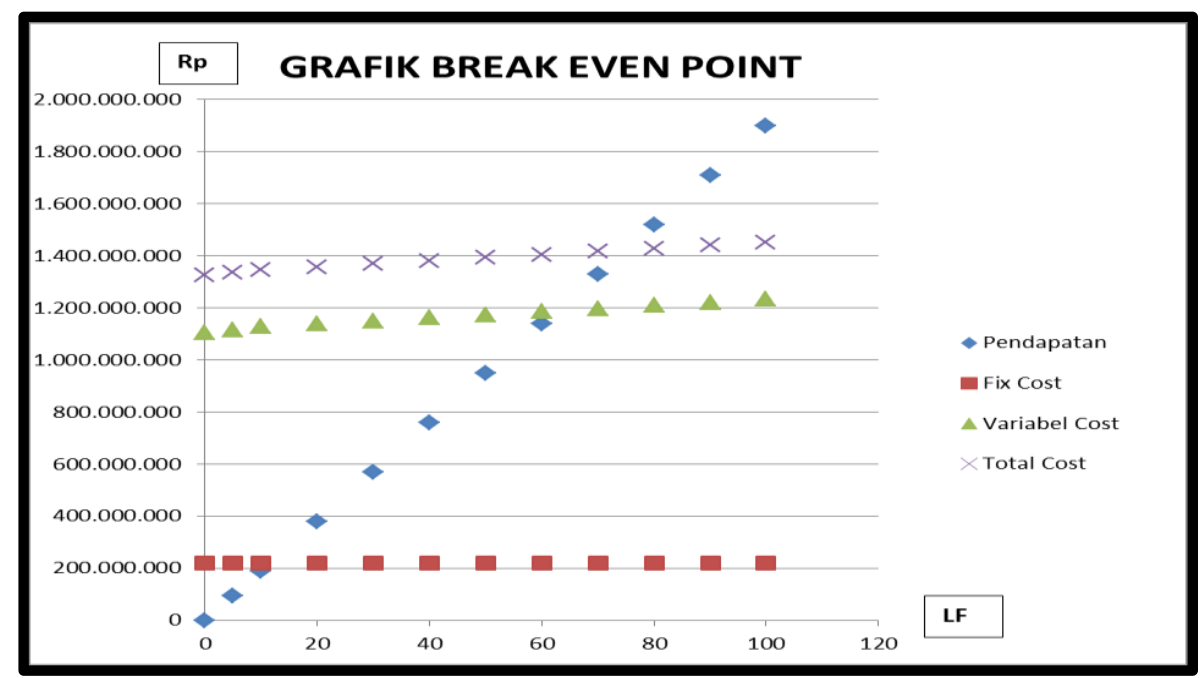




\section{Gambar 2 Grafik Break Even Point}

\begin{tabular}{|c|c|c|c|r|r|r|r|}
\hline Tabel 4 Load Factor Break Even Point \\
\begin{tabular}{|c|c|c|r|r|r|r|}
\hline No \\
Penumpang
\end{tabular} & Kapasitas & Load Factor & Pendapatan & Fix Cost & Variabel Cost & Total Cost \\
\hline 1. & 0 & 80 & 0 & 0 & 218.700 .000 & 1.105 .837 .750 & 1.324 .537 .750 \\
\hline 2. & 4 & 80 & 5 & 95.040 .000 & 218.700 .000 & 1.116 .896 .128 & 1.335 .596 .128 \\
\hline 3. & 8 & 80 & 10 & 190.080 .000 & 218.700 .000 & 1.128 .065 .089 & 1.346 .765 .089 \\
\hline 4. & 16 & 80 & 20 & 380.160 .000 & 218.700 .000 & 1.139 .345 .740 & 1.358 .045 .740 \\
\hline 5. & 24 & 80 & 30 & 570.240 .000 & 218.700 .000 & 1.150 .739 .197 & 1.369 .439 .197 \\
\hline 6. & 32 & 80 & 40 & 760.320 .000 & 218.700 .000 & 1.162 .246 .589 & 1.380 .946 .589 \\
\hline 7. & 40 & 80 & 50 & 950.400 .000 & 218.700 .000 & 1.173 .869 .055 & 1.392 .569 .055 \\
\hline 8. & 48 & 80 & 60 & 1.140 .480 .000 & 218.700 .000 & 1.185 .607 .745 & 1.404 .307 .745 \\
\hline 9. & 56 & 80 & 70 & 1.330 .560 .000 & 218.700 .000 & 1.197 .463 .823 & 1.416 .163 .823 \\
\hline 10. & 64 & 80 & 80 & 1.520 .640 .000 & 218.700 .000 & 1.209 .438 .461 & 1.428 .138 .461 \\
\hline 11. & 72 & 80 & 90 & 1.710 .720 .000 & 218.700 .000 & 1.221 .532 .846 & 1.440 .232 .846 \\
\hline 12. & 80 & 80 & 100 & 1.900 .800 .000 & 218.700 .000 & 1.233 .748 .174 & 1.452 .448 .174 \\
\hline
\end{tabular}

Sumber : Hasil analisa data 2015

\section{e. Analisis Durasi Wisatawan Pada Hari Kerja dan Hari Libur}

Dari hasil survai dilapangan pada hari kerja Senin dan Kamis, didapatkan rata - rata durasi wisatawan berwisata ke Pulau Beras Basah adalah selama lima jam. Pada hari kerja wisatawan ada yang memulai perjalanan wisatanya dimulai pukul 07:00 WITA hingga pukul 11:00 dan adapula yang berangkat pukul 14:00 dan mengakhiri wisata di Pulau Beras Basah pada pukul 18:00 WITA.

Sedangkan untuk hari libur Sabtu dan Minggu, didapatkan rata - rata durasi wisatawan berwisata ke Pulau Beras Basah adalah selama lima jam. Pada hari libur wisatawan ada yang memulai perjalanan wisatanya dimulai pukul 06:00 WITA hingga pukul 11:00 dan adapula yang berangkat pukul 14:00 dan mengakhiri wisata di Pulau Beras Basah pada pukul 18:00 WITA.

\section{f. Fluktuasi Wisatawan Pulau Beras basah}

Perjalanan wisata menuju Pulau Beras Basah banyak dilakukan wisatawan pada pagi hari, dimulai pukul 06.00 WITA. Pada pagi hari wisatawan sudah banyak yang berada di Pelabuhan Tanjung Laut. Dimana pelabuhan tersebut merupakan titik awal para wisatawan untuk menuju Pulau Beras Basah. Moda yang mengantarkan wisatawan menuju kawasan wisata bahari tersebut berada di Pelabuhan Tanjung Laut. Karakteristik perjalanan wisatawan yang melakukan wisata ke Pulau Beras Basah ada yang berangkat dari pagi hari hingga sore hari dan ada pula yang hanya beberapa jam berada di kawasan wisata bahari tersebut. Pada hari kerja perjalanan wisatawan menuju Pulau Beras Basah tidak seramai pada hari libur. Selain itu ada juga wisatawan yang berangkat dari Pelabuhan Tanjung Laut pada siang hari atau menjelang sore hari. Biasanya beberapa wisatawan hanya ingin menikmati suasana sore hari dan melihat keindahan terbenamnya matahari dari kawasan wisata bahari tersebut.

Sore hari merupakan pilihan yang banyak digunakan wisatawan untuk pulang kembali menuju Pelabuhan Tanjung Laut. Wisatawan mulai melakukan perjalanan pulang pada pukul 15.30 WITA hingga sore hari. Selain itu ada juga wisatawan yang berada dikawasan wisata tersebut hanya beberapa jam saja. Ada yang berangkat dari Pelabuhan Tanjung Laut pada pukul 
06.00 dan pada pukul 11.00 WITA sudah perjalanan pulang kembali. Wisatawan yang berada di kawasan wisata bahari hingga sore hari biasanya banyak terjadi pada hari libur Sabtu dan Minggu dan pada hari libur Nasional. Dimana wisatawan yang banyak mengunjungi kawasan wisata tersebut adalah para pekerja swasta yang memanfaatkan waktu liburnya untuk menikmati keindahan alam yang ada di Pulau Beras Basah tersebut. Wisatawan yang berada di Pulau Beras Basah hingga sore hari digunakan untuk melihat indahnya matahari terbenam dari kawasan wisata tersebut. Sehingga wisatawan yang melakukan perjalanan pulang menuju Pelabuhan Tanjung Laut banyak terjadi pada sore hari.

\section{g. Analisis Penjadwalan Kapal Wisata Bahari}

Untuk memberikan pelayanan angkutan wisata bahari yang teratur perlu dilakukan penjadwalan. Dengan adanya jadwal akan mempermudah masyarakat dalam mengatur perjalanan yang akan dilakukannya. Wisatawan pun akan mudah dalam menentukan kapan akan melakukan wisata ke Pulau Beras Basah. Penjadwalan menjadi sangat penting karena wisatawan perlu mengetahui jadwal pastinya dalam rangka mereka merencanakan perjalanan wisatanya. Penjadwalan kapal wisata bahari dibuat berdasarkan fluktuasi wisatawan baik pada hari kerja dan hari libur. Penjadwalan tersebut dibuat berdasarkan survai pada kondisi wilayah studi. Dari fluktuasi tersebut dapat diketahui karakteristik wisatawan yang melakukan perjalanan wisata ke Pulau Beras Basah. Seberapa lama wisatawan berada di kawasan wisata bahari tersebut, selain itu juga dari fluktuasi tersebut dapat diketahui pada pukul berapa wisatawan banyak melakukan perjalanan menuju Pulau Beras Basah dan begitu pun sebaliknya. Sehingga dengan adanya fluktuasi, sistem penjadwalan yang dibuat akan disesuaikan dengan karakteristik yang ada dan jadwal yang ada akan memudahkan wisatawan apabila akan menggunakan angkutan wisata bahari yang tersedia. Adapun waktu perjalanan dari Pelabuhan Tanjung Laut menuju Pulau Beras Basah dengan kapal rencana adalah 30 menit.

\section{h. Analisis Keterpaduan Moda}

Dalam rangka mendukung terciptanya sistem transportasi yang terpadu, integrasi angkutan wisata bahari terpadu dengan moda angkutan lain merupakan yang perlu diwujudkan. Mengingat berbagai kendala yang dijumpai untuk mengembangkan angkutan wisata yang terpadu dengan moda darat maka sebenarnya dapat diambil langkah untuk memanfaatkan keunggulan moda lainnya untuk kemudian dipadukan dengan moda wisata bahari yang berpadu dengan moda darat. Kota Bontang merupakan salah satu bagian dari Provinsi Kalimantan Timur, selain sebagai kota industri, Kota Bontang juga memiliki keindahan alam yang menawan. Salah satu destinasi wisata yang dimiliki Kota Bontang adalah Pulau Beras Basah. Pulau kecil yang cantik dan menawan sehingga menarik banyak wisatawan yang berkunjung ke pulau tersebut. Moda yang digunakan para wisatawan untuk menuju pulau tersebut adalah kapal. Kapal yang ada sekarang masih menggunakan kapal ikan nelayan, sehingga fasilitas dari kapal tersebut masih belum memadai. Dengan banyaknya wisatawan yang berkunjung ke Pulau Beras Basah maka dilakukan perencanaan angkutan wisata bahari yang terpadu dengan moda darat. Keterpaduan moda yang direncanakan tersebut dimaksudkan untuk mempermudah wisatawan dalam melakukan wisata ke Pulau Beras Basah. Fasilitas integrasi angkutan harus didesain sedemikian rupa untuk memperhatikan kebutuhan saat ini, yaitu efisiensi serta kebutuhan di masa mendatang harus di rencanakan semaksimal mungkin.

Dalam menentukan sistem tarif didasarkan pada Peraturan Daerah (Perda), namun di Kota Bontang belum adanya peraturan yang mengatur tarif maka Walikota Bontang mengeluarkan keputusan mengenai tarif yang berlaku di Kota Bontang untuk angkutan umum. Adapun menurut Keputusan Walikota Bontang Nomor 181 Tahun 2015 Tentang Penetapan Tarif Angkutan Kota, 
Angkutan Perkotaan, Angkutan Perbatasan Dan Angkutan Pelajar/Mahasiswa Dalam Wilayah Kota Bontang, bahwa tarif dasar angkutan kota wilayah perkotaan menurut jarak jauh dekat ditetapkan sebesar Rp. 6000,- (Enam Ribu Rupiah). Dengan adanya keputusan Walikota Bontang, untuk menentukan tarif dalam keterpaduan dengan moda darat maka ditentukan tarif sebagai yang tetuang dalam Keputusan Walikota Bontang tersebut.

Moda yang disediakan untuk wisatawan dapat berupa bus sebagai moda pengumpan bagi wisatawan yang tidak menggunakan kendaraan pribadi. Bus dapat melayani wisatawan baik dari dalam Kota Bontang ataupun luar Kota Bontang. Bus beroperasi melayani wisatawan dari Pelabuhan Tanjung Laut melintasi jalan arteri Kota Bontang hingga ke simpul terminal, sehingga wisatawan yang berasal dari luar Kota Bontang dapat dengan mudah berganti moda di terminal untuk melanjutkan perjalanannya. Selain itu, moda pengumpan ini dapat digunakan oleh masyarakat Kota Bontang. Dimana disepanjang rute bus ini di buatlah shuttle bus untuk mempermudah wisatawan dalam menunggu moda pengumpan ke Pulau Beras Basah. Dengan tersedianya moda darat seperti bus pengumpan sebagai moda pendukung angkutan wisata yang terpadu dengan kapal wisata bahari maka akan tercipta transportasi wisata yang terintegrasi dengan baik.

\section{i. Analisis Ekonomi dan finansial}

Dalam analisis finansial dari adanya trayek rencana angkutan wisata Pulau Beras Basah di Kota Bontang dengan adanya trayek angkutan wisata Pelabuhan Tanjung Laut - Pulau Beras Basah yang salah satu pelayanan yang diberikan adanya tarif yang diberlakukan. Dengan adanya tarif rencana maka dapat diketahui keuntungan finansial yang akan didapat dari operator dengan menggunakan kapal yang ada pada kondisi tahun 2017 sampai tahun 2027 yaitu 10 tahun beroperasi dari tahun 2018. Dari hasil analisis finansial angkutan wisata Pulau Beras Basah, Net Present Value dihitung selama 10 tahun yaitu dari tahun 2017 sampai tahun 2027 menghasilkan nilai NPV untuk angkutan wisata Pulau Beras Basah sebesar Rp 31.457.460. Dengan demikian dapat dinyatakan efektif ditinjau dari segi finansial atau investasi. Internal Rate of Return yang dilakukan selama 10 tahun menghasilkan IRR untuk angkutan wisata Pulau Beras Basah sebanyak $32 \%$, yang menunjukkan suku bunga lebih tinggi dari Sosial Opportunity Cost of Capital (7,5\%). Dengan demikian dari hasil analisis juga layak secara finansial atau investasi. Analisis dalam perhitungan NPV menghasilkan Net B/C untuk angkutan wisata Pulau Beras Basah sebesar 2,2 ini lebih besar dari pada 1 dan dapat dinyatakan pula bahwa layak secara finansial atau investasi.

\section{KESIMPULAN}

Berdasarkan hasil analisis forcasting/peramalan wisatawan yang didukung dari jumlah kunjungan wisatawan lima tahun terakhir. Maka dapat ditarik kesimpulan jumlah wisatawan untuk setiap tahunnya meningkat. Peningkatan pertumbuhan wisatawan setiap tahunnya setiap tahunnya meningkat sebesar 0,12 atau 12\%. Ini menunjukkan bahwa kawasan wisata bahari Pulau Beras Basah banyak dikunjungi wisatawan, baik wisatawan dari dalam Kota Bontang ataupun luar Kota Bontang. Pola operasi kapal pada kondisi rencana yaitu frekuensi kapal rata-rata 9 trip/hari, dengan kemampuan trip kapal 6 trip/kapal/hari dengan waktu operasional dermaga 12 jam perhari dan jumlah kebutuhan kapal pada kondisi rencana 2018 sebanyak 2 (dua) kapal.

Untuk angkutan wisata bahari Pulau Beras Basah akan mengalami titik impas pada load faktor BEP 75\% dari load faktor kapal rencana 70\%. Sehingga dapat dikatakan kondisi operasional angkutan wisata bahari lintas Pelabuhan Tanjung Laut - Pulau Beras Basah mengalami titik impas atau menguntungkan pada saat load faktor BEP 75\%. Jadwal kapal pada kondisi rencana dibuat berdasarkan hari libur dan hari kerja. Dengan jumlah kapal pada kondisi 
rencana sebanyak dua kapal. Adapun waktu perjalanan dari Pelabuhan Tanjung Laut menuju Pulau Beras Basah dengan kapal rencana adalah 30 menit.

\section{REFERENSI}

1. Undang - undang Nomor 10 Tahun 2009 tentang Kepariwisataan

2. Yoeti, O. A. (1994). Pariwisata dan lingkungan hidup. Angkasa.

3. Peraturan Pemerintah Nomor 50 Tahun 2011 tentang Rencana Induk Pembangunan Kepariwisataan Nasional Tahun 2012-2025.

4. Soekadijo, R. G. (1996). Anatomi Pariwisata Indonesia. Jakarta: Gramedia.

5. Damardjati, R. S. (2007). Istilah-istilah Dunia Pariwisata. Jakarta: Pradya Paramita.

6. Seaton, B. (1996). Karakteristik Perjalanan Wisatawan.

7. Peraturan Direktur Jenderal Perhubungan Darat Nomor: SK.242/HK.104/DRJD/2010 tentang Pedoman Teknis Manajemen Lalu Lintas Penyeberangan. 